[Radiocarbon, Vol. 6, 1964, P. 77-90]

\title{
UNIVERSITY OF ROME CARBON-14 DATES II
}

M. ALESSIO and F. BELLA

Istituto di Fisica, Università di Roma. Istituto Nazionale di Fisica Nucleare,

Sezione di Roma

\section{CORTESI}

Istituto di Geochimica, Università di Roma

A first list of datings by our laboratory was published in 1957 (Bella and Cortesi, 1957). The measurements were performed with a solid Carbon counter (Ballario et al., 1955). Between the beginning of 1958 and December 1961 laboratory apparatus was completely renewed and proportional gas-counters were introduced. At present four counters are available. Measurements are carried out with $\mathrm{CO}_{2}$ at 3 atm pressure.

Only two counters have been used for datings, the first one of $1.5 \mathrm{~L}$, a model already described (Bella and Cortesi, 1960), with present background $3.66 \pm 0.11$ counts $/ \mathrm{min}$, and counting rate for modern carbon $30.56 \pm 0.18$ counts/min. The characteristics of the second one are efficient volume $1 \mathrm{~L}$, length of wire $360 \mathrm{~mm}$, diam of wire $0.05 \mathrm{~mm}$, internal diam of the counter $60 \mathrm{~mm}$, supply voltage 8,600 volts, background $12.88 \pm 0.14$ counts $/ \mathrm{min}$, counting rate for modern carbon $30.65 \pm 0.18$ counts $/ \mathrm{min}$. The high background of this counter is due to the insufficient length of the G.M. anticoincidence counters. In fact, the counter was designed for insertion in a particular circuit for the purification of the filling gas. This circuit is still at an experimental stage and will be described in a forthcoming paper. The shielding is the same as that used in the $1.5 \mathrm{~L}$ counter. The dates obtained with the two counters agree completely within the errors.

Three new independent channels of electronic recording have been built; they are similar to the one already described (Bella and Cortesi, 1960) except that a few modifications have been introduced to provide greater stability of the pulse length.

Some minor modifications in the way $\mathrm{CO}_{2}$ is prepared have been introduced; purest $\mathrm{CO}_{2}$ is obtained by means of the purification method already described (Bella and Cortesi, 1960) combined with initial precipitation as $\mathrm{CaCO}_{3}$ of the $\mathrm{CO}_{2}$ resulting from the combustion of samples.

All samples undergo standard pre-treatment by boiling with 2 to $5 \%$ $\mathrm{HCl}$. If necessary, an additional leaching with $6 \% \mathrm{NH}_{4} \mathrm{OH}$ is made, followed by a new $\mathrm{HCl}$ treatment of the sample, which is finally washed with distilled water.

In accordance with the instructions of the editors, ages have been calculated using Libby's half-life average for $\mathrm{C}^{14} 5568 \pm 30 \mathrm{yr}$ with 1950 as the standard year of reference. A modern wood grown near Rome between 1949 and 1953 has been used as modern standard. Its activity was checked by measurements of known age samples and judged satisfactory.

The list comprises age measurements carried out between January 1962 and July 1963; the samples dated are of archaeological and geological interest and are almost exclusively drawn from Italian territory. 


\section{ACKNOWLEDGMENTS}

We wish to express our thanks to the Consiglio Nazionale delle Ricerche which has provided partial financial support. The help of Dr. Fiorella Bachechi, an assistant in our laboratory, in carrying out measurements is gratefully acknowledged.

\section{SAMPLE DESCRIPTIONS}

I. CROSS-CHECK SAMPLES

\section{R-1. Lake of Nemi, Italy}

Externally charred wood from remains of one of two Roman vessels that, until 1927, were lying at the bottom of the Lake of Nemi, Alban Hills, near Rome $\left(40^{\circ} 43^{\prime} \mathrm{N}\right.$ Lat, $12^{\circ} 42^{\prime} \mathrm{E}$ Long). As a result of warfare in the neighbourhood in May 1944, a fire broke out, destroying the lakeside museum housing these vessels, of which only a few timber beams survived. Through the interest and with the authorization of the Soprintendente alle Antichita Roma I, S. Aurigemma in 1952, and of his successor, P. Romanelli in 1954, two pieces of wood from the same beam were submitted to our lab. The wood in question is Pinus (probably Pinus laricio) and in an excellent state of preservation. In the section 30 tree-rings were visible but these do not establish the age of the tree owing to absence of central portion and the combustion of outer part. Comment: historical date of this wood is known since construction of ships can be assigned with fair certainty to the reign of Caligula (A.D. 37 to 41). In 1955 it was distributed by our lab. as a cross-check sample, after being dated several times with a solid carbon counter, the average of six measurements being $2125 \pm 75$ (Bella and Cortesi, 1957). The date given above is closer to the historical age and was measured with a $\mathrm{CO}_{2}$ proportional counter. Dates obtained by other labs.: T-9, $1880 \pm 130$ (Nydal and Sigmond, 1957); St-103A/B, average: $2010 \pm 65$ (Stockholm I) ; BM-15, $2080 \pm 150$ (British Museum I) ; Q-112, 1904 \pm 95 (Cambridge I) ; U-68, $1980 \pm 70$ (Uppsala I). A preliminary date $(2290 \pm 100 \mathrm{yr})$ was obtained by the Radiocarbon Dating Lab., Inst. of Applied Sci. of Victoria, Australia (Focken, 1960).

\section{R-64. Ruds Vedby}

Wood from a thin dark layer of peaty lake mud forming pollen zone boundary II/III, Alleröd-Younger Dryas; Ruds Vedby, Zealand, Denmark $\left(55^{\circ} 32^{\prime} \mathrm{N}\right.$ Lat, $11^{\circ} 22^{\prime} \mathrm{E}$ Long). Comment: distributed by H. Tauber as cross-check sample (K-101) and dated by many European labs. and by USGS lab. Dates obtained range from 10,200 to $11,500 \mathrm{yr}$ : K-101bis, K-102bis, K-103bis, average: 11,030 \pm 200 (Copenhagen III) ; Gro-454, 10,995 \pm 250 (Groningen II) ; St-18, 10,200 \pm 370 (Stockholm I) ; U-20, 10,830 \pm 130 and U-75, 10,680 \pm 130 (Uppsala I) ; H-105, 11,500 \pm 300 (Heidelberg I) ; BM-19, 11,333 \pm 300 (British Museum I) ; W-82 and W-84, average: 10,400 \pm 160 (USGS I). Ages obtained by U. S. Geol. Survey are reckoned too young. Our measurement results in a somewhat older age comparable only with that obtained by Heidelberg. The boundary between the phase of Alleröd and Younger-Dryas has been fixed, especially by Copenhagen and Groningen dates, around $11,000 \mathrm{yr}$. 


\section{R-106. Usselo}

$11,800 \pm 280$

9850 B.C.

Wood (Betula) found in peat from the section near Usselo $\left(52^{\circ} 10^{\prime} \mathrm{N}\right.$ Lat, $6^{\circ} 50^{\prime}$ E Long), province of Overijssel, Netherlands. Sample given us by Hl. De Vries at Groningen in November 1957. Belongs to same level as samples Gro-933 and Gro-948 (Alleröd phase) and, like them, was obtained during Usselo 1955 excavations by C. C. W. J. Hijszeler, Rijksmuseum Twenthe, Enschede. Comment: the Usselo section corresponds to Profile B of van der Hammen (van der Hammen, 1951) (Groningen II). In the succession of layers made up of moss peat mixed with dune sand, pollen analysis has allowed identification of zones belonging to well-known succession of late Würm stadials and interstadials already distinguished in Denmark: Oldest Dryas-BöllingOlder Dryas-Alleröd. Sample R-106 belongs to Alleröd phase, and date obtained agrees well with Gro-933, 11,875 \pm 120 and Gro-948, 11,515 \pm 120 , average: $11,700 \pm 90$ (Groningen II). Samples from section near Usselo, corresponding to the van der Hammen profile and Alleröd phase, but obtained during preceding excavation campaign and submitted in 1951 by R. D. Crommelin, have been dated by Yale Lab. Y-139/1/2/3 (Yale III). The whole Usselo series has been dated also by Copenhagen Lab., samples K-541 to K-547, K-552 and K-553 (Copenhagen IV). Dates obtained at Copenhagen agree well with those of Groningen.

\section{ARCHAEOLOGIC SAMPLES}

$$
\text { A. Italy }
$$

\section{R-83. Palidoro}

$13,000 \pm 700$

11,050 в.c.

Charred bones from lower level of Palidoro deposit, Via Aurelia, $30 \mathrm{~km}$ W of Rome $\left(41^{\circ} 55^{\prime} \mathrm{N}\right.$ Lat, $12^{\circ} 11^{\prime}$ E Long). Coll. and subm. by V. G. Chiappella, Ist. Italiano di Paleontologia Umana, 1956. Excavation between 1956 and 1959 at $\mathrm{N}$ edge of a travertine quarry revealed archaeological layers containing in the higher levels bones of domestic animals and potsherds belonging to the Middle Age, the Roman period, the Iron and Bronze Ages and Middle Neolithic period. A bone-breccia with charred bones (Bos, Equus, Cervus, Sus) containing flint implements of a fine Upper Paleolithic industry of Gravettian type formed the lower level and was considered to be part of a deposit in a small cave or shelter destroyed by quarry-working (Chiapella, 1956 and 1962). Comment: owing to the plentiful supply of charred bones only bits of compact bone tissue, less liable to contamination, have been used for dating purposes. After careful washing, the bone's mineral components were completely destroyed by repeated treatment with $10 \% \mathrm{HCl}$; measurement was carried out on blackish humic matter which was wholly soluble by $6 \% \mathrm{NH}_{4} \mathrm{OH}$. The calculated age agrees with the type of industry at this level.

\section{R-58. Grotta Romanelli}

$$
\begin{aligned}
& 11,800 \pm 600 \\
& 9850 \text { B.C. }
\end{aligned}
$$

Charcoal found at ca. $30 \mathrm{~cm}$ below surface in upper Level A of the "terra bruna" formation of the deposit in Grotta Romanelli, Costiera Salentina, $2 \mathrm{~km}$ from Castro toward S. Cesarea, province of Lecce, Apulia $\left(40^{\circ} 01^{\prime} \mathrm{N}\right.$ Lat, $18^{\circ} 24^{\prime}$ E Long). Coll. and subm. by the late A. C. Blanc and L. Cardini, 
Ist. Italiano di Paleontologia Umana, 1954. Comment: fresh excavation carried out in Grotta Romanelli to collect series of "terra bruna" samples in unexplored area of the formation so as to use the humus for dating purposes. Since "terra bruna" contains industry of the Romanellian culture of Upper Palaeolithic Age, charcoal resulting from human activity was carefully looked for and found. According to G. A. Blanc's interpretation (Blanc, G. A., 1920, 1928; Blanc and Cortesi, 1941), the "terra bruna" and underlying "terra rossa" of the deposit were brought into the cave by the wind from the coastal plain, which at that time stretched out in front of the cave, remaining unchanged till the present day. The two formations are, then, termed "palaeosoils" since they represent two types of climatic soil appearing successively in this area. The idea occurred of dating the "terra bruna" by means of the humus extracted from it (Blanc, A. C. and Blanc, G. A., 1958). Dating of humic acids at intermediate Level B of the "terra bruna" was carried out by this lab. with a solid-carbon counter (R-56, 11,960 \pm 320$)$; the method of humus extraction has been described and the age commented on (Bella, Blanc, A. C., Blanc, G. A., and Cortesi, 1958). The agreement with the age obtained for sample R-58 (charcoal) is particularly significant as the charcoal does not belong to the soil but was deposited contemporaneously with it. Moreover, the age is that expected for Romanellian culture.

A number of charcoal samples from levels A, C, and D of the "terra bruna," also found during 1954 excavation, have been dated at Groningen: $A_{2}$. GrN-2056, $9880 \pm 100 ; \mathrm{A}_{3}, \mathrm{GrN}-2305,10,320 \pm 130 ; \mathrm{C}_{1}, \mathrm{GrN}-2153,10,390$ $\pm 80 ; \mathrm{C}_{2}, \mathrm{GrN}-2154,9790 \pm 80 ; \mathrm{D}, \mathrm{GrN} \cdot 2055,10,640 \pm 100$ (Groningen IV). Ages obtained at Groningen are in every case younger than those of our lab., and all but one (GrN-2154) follow the stratigraphical order.

\section{Grotta del Pertusello series}

Excavation of the Grotta del Pertusello deposit, Val Pennavaira, province of Savona, Liguria (44. $06^{\prime}$ N Lat, $7^{\circ} 59^{\prime} 16^{\prime \prime} \mathrm{E}$ Long) was begun by V. G. Chiappella and concluded by M. Leale Anfossi, Ist. Italiano di Paleontologia Umana. Samples coll. in 1957 and 1958 and subm. at that time by M. Leale Anfossi. Throughout the deposit numerous hearths have been found together with charred bones of domestic and wild animals and ash-heaps. Three layers (II, III, IV) have been identified, containing pottery that can be assigned to late Neolithic (Layer IV) and the Iron Age (upper Layers III and II). Only at Layer IV were flint implements found (M. Leale Anfossi, 1958-6la,b). The Grotta del Pertusello (No. 304 in the "Catalogo Speleologico Ligure") is the first of numerous Ligurian prehistoric settlements to be dated.

\section{R-113. Pertusello II}

$$
\begin{gathered}
2100 \pm 80 \\
150 \text { в.C. }
\end{gathered}
$$

Charcoal, 10 to $38 \mathrm{~cm}$ below surface. Brownish earth with coarse corded pottery of Iron Age.

\section{R-114. Pertusello III}

$2970 \pm 90$

1020 в.C.

Charcoal, 38 to $63 \mathrm{~cm}$ below surface. Light-brown earth, with polished pottery of "Lagozza" type of Late Eneolithic. 
R-122. Pertusello IV

Charcoal 63 to $70 \mathrm{~cm}$ below surface. Grey ash with whitish clay, containing pottery with hemispheric bottom and cardial decoration, and flint blades of Upper Neolithic.

General Comment: the ages obtained seem to agree with those expected for industries discovered in the layers.

\section{R-78. Lagozza di Besnate}

$4200 \pm 300$

2250 в.C.

Part of a Neo-Eneolithic wooden pile from the Lagozza di Besnate, province of Varese, Lombardy (45 $42^{\prime} \mathrm{N}$ Lat, $8^{\circ} 46^{\prime}$ E Long). Coll. 1953 and subm. 1956 by O. Cornaggia-Castiglioni, Soprintendenza ai Monumenti, Milan. Com$m e n t$ : in this area the lake dwellings excavated and illustrated by 0 . CornaggiaCastiglioni (Cornaggia-Castiglioni, 1955) revealed a typical Upper Neolithic culture (Lagozza Culture). Another pile sample from same area has been dated at Pisa: Pi-34, 4794 \pm 90 (Pisa II).

\section{R-66. Grotta del Fauno}

$$
3500 \pm 250
$$

1550 в.C.

Powdered charcoal and minute charcoal fragments from a lime-mould forming a bed, $50 \mathrm{~cm}$ thick, underlying rubble layer, $1.5 \mathrm{~m}$ thick, of deposit in Grotta del Fauno, Parco Nazionale degli Abruzzi, $13 \mathrm{~km}$ SE Pescasseroli $\left(41^{\circ}\right.$ $44^{\prime} \mathrm{N}$ Lat, $13^{\circ} 50^{\prime} \mathrm{E}$ Long). Deposit made up of rubble with bed of charcoal and ash. Upper part is of Roman period; lower part contains pre-Roman and Iron Age pottery. Bottom of deposit not yet explored. Coll. and subm. 1955 by A. M. Radmilli, Ist. di Antropologia e Paleontologia Umana, Univ. of Pisa. Comment: charcoal taken from upper section of pre-Roman stratum has been dated at Pisa, Pi-1, $2318 \pm 105$ (Pisa II).

\section{R-29A. Grotta Polesini}

$$
\mathbf{5 8 0} \pm \mathbf{5 0}
$$

Charcoal from the Grotta Polesini deposit on bank of river Aniene, Ponte Lucano, near Tivoli, Lazio $\left(41^{\circ} 57^{\prime} \mathrm{N}\right.$ Lat, $12^{\circ} 46^{\prime} \mathrm{E}$ Long). Deposit contains Iron Age, Bronze Age and Upper Paleolithic levels with industry of Romanellian type (Radmilli, 1953). Charcoal subm. for dating was thought to be contemporary with latter level. Coll. and subm. 1953 by A. M. Radmilli. Comment: material is more recent than supposed, and probably belongs to a section deposited or altered by the river Aniene.

\section{R-9. Grotta Misa}

$$
\begin{aligned}
& 2460 \pm 100 \\
& 510 \text { в.C. }
\end{aligned}
$$

Charcoal from the Grotta Misa deposit, Ischia di Castro, province of Viterbo, Lazio $\left(42^{\circ} 30^{\prime} \mathrm{N}\right.$ Lat, $11^{\circ} 38^{\prime} \mathrm{E}$ Long). Charcoal found together with burnt beans and millet. A Late Bronze Age culture represented in the deposit by bronze objects and pottery. Excavated 1947 by L. Cardini, F. Rittatore and E. Tongiorgi; subm. 1951 by E. Tongiorgi, Lab. di Geologia Nucleare, Univ. of Pisa. Comment: charcoal from same deposit has been dated at Pisa Pi-54, $3030 \pm 75$ (Pisa II). 


\section{R-10. Etruscan ovens}

Charcoal from Etruscan ovens, Valle del Temperino $1 \mathrm{~km} \mathrm{~N}$ Campiglia Marittima, province of Leghorn, Tuscany $\left(43^{\circ} 03^{\prime} \mathrm{N}\right.$ Lat, $10^{\circ} 10^{\prime} \mathrm{E}$ Long). Coll. 1936 and subm. 1951 by E. Tongiorgi. Comment: Commission for the study of Old Mine Working Activities of the Soprintendenza alle Antichità dell' Etruria, excavated six Etruscan ovens here in 1936. They were identified, through study of the slag, as copper manufacturing furnaces. Charcoal belongs to Quercus robur, Quercus cerris and Pirus aucuparia (Tongiorgi, 1937). Other archaeological finds have afforded no sure indication of historical age (D'Achiardi e Stefanini, 1937). Date obtained corresponds to last phase of Etruscan civilization.

\section{R-7. Lago di Ledro}

$3310 \pm 210$

1360 B.c.

Charcoal found next to Layer III under remains of stacked platform of lake dwellings in Lago di Ledro $7 \mathrm{~km}$ SE Riva del Garda, province of Trento (45 $51^{\prime}$ N Lat, $10^{\circ} 43^{\prime}$ E Long) (Battaglia, 1953). Coll. 1937 and subm. 1951 by the late R. Battaglia, Direttore dell'Ist. di Antropologia, Univ. of Padua. Comment: part of wooden piling of lake dwelling dated in Pisa: Pi-88, $3137 \pm$ 105 (Pisa II).

\section{R-3. Sarsina}

$$
1900 \pm 80
$$

A.D. 50

Charred wood found during excavations of necropolis of Pian di Bezzo, Sarsina, province of Forli, Romagna $\left(43^{\circ} 56^{\prime} \mathrm{N}\right.$ Lat, $12^{\circ} 08^{\prime}$ E Long). Subm. 1952 by S. Aurigemma, formerly Soprintendente alle Antichità, Roma I. Comment: necropolis belongs to Roman epoch and date obtained agrees with this.

\section{R-63. Sardinia}

A.D. 1610

$$
340 \pm 60
$$

Wood from oak beam thought to belong to structure of Sardinian Roman bridge (locality unspecified) and housed in Museo delle Navi Romane, Lake of Nemi, Rome. Subm. 1954 by P. Romanelli, formerly Soprintendente alle Antichità, Roma I. Comment: age obtained refutes attribution, the object being of recent date.

\section{R-92A. Fiumicino$$
1890 \pm 90
$$ \\ R-92B. Fiumicino

$$
\begin{array}{r}
\text { A.D. } 60 \\
1850 \\
\text { A.D. } 100
\end{array} \pm \mathbf{8 5}
$$

Portion of wooden pile forming part of foundations of Roman port of time of Emperor Claudius (41 to 54 A.D.) at Fiumicino, Rome (41 $46^{\prime} \mathrm{N} \mathrm{Lat,} 12^{\circ}$ 15’ E Long). Subm. 1957 by G. Iacopi, Soprintendente alle Antichità Roma I. Comment: supporting piles and boards of a palisade came to light in sandy terrain at about $8 \mathrm{~m}$ depth during excavation directed by G. Iacopi. The pile in question was ca. $20 \mathrm{~cm}$ in diam, the inner part very well preserved, the outer part impaired to a depth of 5 to $8 \mathrm{~cm}$. Hence two different samples were prepared: R-92A, wood from the impaired section, and R-92B, well-preserved wood. The identical ages obtained show that no contamination occured in the impaired portion (see also R-22A and R-22B, this date list). 
The archaeologists had thought piling and planking belonged to Roman port. However, some doubts expressed owing to excellent state of preservation of palisade. The two dates for the pile and that of a plank of the palisade (measured at Pisa, Pi-3A, $1863 \pm 135$; Pisa I), have cleared up all doubts.

\section{Roman Forum series}

Samples of varying interest have been found during excavations carried out at different times in the Roman Forum, Rome $\left(40^{\circ} 54^{\prime} \mathrm{N}\right.$ Lat, $12^{\circ} 27^{\prime} \mathrm{E}$ Long). Subm. 1952 by P. Romanelli and G. Carettoni, Soprintendenza alle Antichità, Roma IV, Foro Romano, and S. Puglisi, Soprintendenza alle Antichità, Roma V.

\section{R-17. Roman Forum 1}

$$
2120 \pm 190
$$

170 в.C.

Wood fragment of beam from roof of Basilica Emilia. Subm. by P. Romanelli and G. Carettoni. Comment: date obtained agrees with historical age of the building of the Basilica.

\section{R-19. Roman Forum 3}

$$
\begin{gathered}
2600 \pm 150 \\
650 \text { в.C. }
\end{gathered}
$$

Fragment of oak sarcophagus from a Roman Forum tomb belonging to the second Latial phase. Subm. by S. Puglisi. Comment: presumed historic age (ca. 580 B.c.) agrees with the date obtained.

\section{R-20. Roman Forum 4}

$2280 \pm 250$

330 B.C.

Wood from the foundations of Republican buildings near the Temple of Antonino and Faustina. Subm. by P. Romanelli. Comment: expected age: 2nd half of lst century B.C.; date obtained agrees satisfactorily.

\section{R-21. Roman Forum 5}

$$
2360 \pm 85
$$

Charred wheat and barley found in archai by A Bartoli during the 1930 excavations (Bartoli, 1961) and subm by S. Puglisi. Comment: the presumed historical age (ca. 550 B.C.) is in agreement with the date obtained.

\section{R-22A. Roman Forum 6a$$
2280 \pm 90
$$$$
330 \text { в.C. }
$$ \\ R-22B. Roman Forum $6 b$ \\ $2260 \pm 80$ \\ 310 в.c.}

Wood recognized as a beam from foundations of Temple of Divus Julius found during excavations by $R$. Gamberini Mongevet and subm. by $P$. Romanelli. Comment: sample R-22A was taken from the impaired outer part of the wood, sample R-22B from the well-preserved inner part. Both samples were treated with $5 \% \mathrm{HCl}$ (see R-92A and R-92B). The two dates coincide, but are somewhat older than the historical age expected (ca. 40 B.C.). It is thought that the foundations are likely to be older.

General Comment: the above samples, and pieces of charcoal from a layer in the road foundations of Sacra Via, dated at Stockholm (St-315, $2525 \pm 75$; Stockholm II), are the only materials from the different archaeological layers of the Roman Forum that have been dated as yet. 


\section{R-35. Asyut, Egypt}

\section{B. Africa}

$3880 \pm 80$

1930 в.c.

Shapeless fragment of wooden basket in excellent state of preservation forming part of statue bearing offerings, Asyut, Upper Egypt (27 $10^{\prime} \mathrm{N} \mathrm{Lat,}$ $31^{\circ} 10^{\prime}$ E Long) lodged in Museo Egizio of Turin. Subm. 1954 by E. Scamuzzi, Soprintendente alle Antichità, Egittologia, Turin II. Comment: statuette is classified as belonging to Middle Dynasty, dated, according to new Egyptian chronology, 1800 to 2000 B.c. Date obtained agrees well with, and confirms, the expected historical age.

\section{R-37. Egypt}

$2410 \pm 50$

460 в.c.

Wooden fragment from coffin from Egyptian Ptolemaic period; original location in Egypt is not known. Sample used to belong to the Drovetti Collection at the Museo Egizio of Turin. Subm. 1954 by E. Scamuzzi. Comment: accepted age: 3rd to 4th century B.c.; date obtained agrees satisfactorily. Wood from another coffin of the Ptolemaic period has been dated by Libby: C.62, $2190 \pm 450$ (Chicago I), and the same sample was more recently dated by the Univ. of California : UCLA-109, $2360 \pm 75$ (UCLA I).

\section{R-23. Philip Cave, Southwest Africa}

$$
\mathbf{2 8 0} \pm \mathbf{8 0}
$$

A.D. 1670

Charcoal fragments, 2 to $3 \mathrm{~cm}$ in diam, found on surface, Philip Cave (Ameib) SE of Erongo Mountains, Windhoek region, SW Africa (ca. $22^{\circ} 00^{\prime}$ S Lat, $16^{\circ} 20^{\prime}$ E Long). Coll. 1950 and subm. 1952 by the late H. Breuil. Comment: owing probably to a spring that in the past had deposited calcareous tufa, this charcoal was so strongly lithified by $\mathrm{CaCO}_{3}$ that the fragments had to be reduced to fine powder before the carbonate could be wholly eliminated by repeated treatment with $10 \% \mathrm{HCl}$. In spite of his doubts about such surface samples, H. Breuil asked for them to be dated since, as well known, the walls of Philip Cave are covered with paintings of great interest. Age obtained showed that the material was fairly recent. Another charcoal sample from Philip Cave was carefully taken during regular excavation and subm. by H. Breuil to the Chicago Lab. for dating: C-911, $3368 \pm 200$ (Chicago V). This date was accepted by $H$. Breuil (1954) as an indication of the age of the principal cycle of paintings in the cave.

\section{Asia}

\section{Andaman Islands series, Indian Ocean}

The Italian anthropologist and explorer, Lidio Cipriani, who died in October 1962, made several visits to the Andaman Islands between 1951 and 1955, carrying out risky but successful explorations for anthropological, ethnological, and palaeo-ethnological studies of the native Andaman population. The people, now nearly extinct, belong to the Asian group of pygmies or Negritos. As is well known, they are nomads and very fierce and primitive, still living today exclusively by hunting, fishing and food-gathering. Cipriani attached great importance to the excavation of the many kitchen-middens, evidently of different periods, that are widely scattered throughout the archipelago. 
The nomadic populations made and abandoned these middens over an undefined and, it would seem, extensive period of time (Cipriani, 1955, 1958-61, 1962).

In August 1956, through G. A. Blanc, L. Cipriani subm. to our lab. charcoal samples that he had coll. at well-defined levels during the excavation of two kitchen-middens in 1953.

\section{R-84. North Andaman Island (Great} Andaman)

Charcoal found in midden in Maya Bander area (ca. $13^{\circ} 15^{\prime} \mathrm{N}$ Lat, $93^{\circ}$ $00^{\prime}$ E Long), from Section II NS in deeper layer with Arca, extending downward to virgin soil ca. $2.5 \mathrm{~m}$ below surface level of excavation. Original depth of the layer was greater, as the middens were reduced by erosion. Coll. 1953 by L. Cipriani; subm. 1956.

\section{R-85. North Andaman Island (Great Andaman )}

Charcoal from same midden as R-84, from section EW in the upper layer with Arca, ca. $1.60 \mathrm{~m}$ below surface level of excavation. Coll. 1953 by L. Cipriani; subm. 1956.

\section{R-86. Middle Andaman Island (Great}

\section{Andaman )}

$370 \pm 80$

Charcoal from kitchen-midden on $\mathrm{W}$ coast near Long Island at foot of Golpahar (Beehive Hill) (ca. $12^{\circ} 40^{\prime} \mathrm{N}$ Lat, $92^{\circ} 40^{\prime} \mathrm{E}$ Long) at depth of $3 \mathrm{~m}$ below surface level of excavation. Coll. 1953 by L. Cipriani; subm. 1956. General Comment: ages obtained show that the two middens are of fairly recent date. Moreover, the identical ages of $\mathrm{R}-84$ and $\mathrm{R}-85$ reveal the rapid growth of the middens and the frequent shifting of the population. Cipriani inferred that the two middens went back some thousands of years (Cipriani, 1962). When informed of the measurements (September 1962), he recognized that his deductions had been wrong, but believed that older middens must certainly be scattered about the Andaman Islands. In his view, however, their identification would be more difficult because they were abandoned for a longer time and were now most likely hidden by tropical forest.

$$
\text { III. GEOLOGIC SAMPLES }
$$

\section{A. Italy}

With the exception of R-39, the samples dated so far are peats of Holocene age from localities in the Alps and the Italian coastal plains. Systematic dating of other Italian formations is planned.

\section{Val di Susa and Val Chisone series, Alpi Cozie, Piedmont}

A stratigraphical, palaeontological and palynological survey of the postWürm lacustrine formations of Val di Susa and the nearby Val Chisone is being carried out by G. Charrier, Ist. di Giacimenti Minerari, Politecnico. Turin. The aim is to establish correlations with the scattered remains of these formations, and explain some singular characteristics of present-day vegetation in the Western Alps. 


\section{R-52. Novaretto, Val di Susa, Piedmont}

Peat from the old Novaretto peat-bog, $2 \mathrm{~km}$ from Comune of Chiavrie, Val di Susa, Piedmont $\left(45^{\circ} 07^{\prime} \mathrm{N}\right.$ Lat, $7^{\circ} 21^{\prime} \mathrm{E}$ Long, $362 \mathrm{~m}$ above sealevel $)$. Sample extracted from peat layer $1 \mathrm{~m}$ thick, at depth of 2 to $3 \mathrm{~m}$ below surface in post-Würm formation preserved in small units in Lower Val di Susa, on left (orographic) side of river Dora Riparia. Profile of bog is as follows: 0 to $-50 \mathrm{~cm}$, agricultural soil ; -50 to $-200 \mathrm{~cm}$, lacustrine clay with mollusc remains; -200 to $-300 \mathrm{~cm}$, sedge (Carex) peat, very compact. Coll. 1947 by Mr. Bronzino who was then working the peat-bog; subm. 1954 by G. Charrier.

\section{R-53. Colle del Sestrière, Val Chisone,} Piedmont

Peat from upper peat bed of peaty depression $\mathrm{E}$ of Albergo Duchi di Aosta, Colle del Sestrière, Val Chisone, Piedmont (44 $57^{\prime} \mathrm{N}$ Lat, $6^{\circ} 53^{\prime} \mathrm{E}$ Long, $2020 \mathrm{~m}$ above sealevel). A section of the formation $2 \mathrm{~m}$ in depth reveals the following profile: 0 to $-50 \mathrm{~cm}$, peaty agricultural soil; -50 to $-60 \mathrm{~cm}$, Sphagnum-peat; -60 to $-150 \mathrm{~cm}$, fluvial-lacustrine, clayey-sandy sediment; -150 to $-158 \mathrm{~cm}$, Sphagnum-peat. Coll. and subm. 1954 by G. Charrier.

General Comment: dates of R-52 and R-53 are in agreement with expected ages of the two peat-bogs which, according to Charrier, represent two stages of bog growth, well separated in time, that interrupted the lacustrine sedimentation on the valley-floor. The Novaretto peat-bog dates from the time of mixed forest (abundant Pinus together with broad-leaved trees) transitional between the Boreal and Atlantic. The Colle del Sestrière peat-bog represents an interesting climatic oscillation in Roman times.

\section{Cervino series, Alta Valtournanche, Piedmont}

Peat and wood from an old peat-bog ca $1 \mathrm{~km} \mathrm{SW}$ of Albergo-Rifugio Lo Riondé, Alta Valtournanche at foot of the M. Cervino, province of Aosta, Piedmont $\left(45^{\circ} 57^{\prime} \mathrm{N}\right.$ Lat, $7^{\circ} 38^{\prime} \mathrm{E}$ Long, $2250 \mathrm{~m}$ above sealevel). Small peatbog crossed by stream at foot of high rock wall. Two samples coll. 1954 at same level ca. $85 \mathrm{~cm}$, in newly-made section, by G. Isetti, Ist. Italiano di Paleontologia Umana; subm. 1956 by E. Tongiorgi.

\section{R-81. Peat, Monte Cervino}

\section{R-82. Wood, Monte Cervino}

Comment: dates a Holocene time when forest grew at higher altitude than present. Pollen analysis of peat being carried out by E. Tongiorgi.

\section{Lago Pirola series}

Peat and wood from old peat-bog on terrace ca. $150 \mathrm{~m}$ E of Lago Pirola, $1 \mathrm{~km} \mathrm{~S}$ of Chiareggio, Val Malenco, province of Sondrio, Lombardy $\left(46^{\circ} 10^{\prime}\right.$ $\mathrm{N}$ Lat, $9^{\circ} 47^{\prime} \mathrm{E}$ Long, 2284 $\mathrm{m}$ above sealevel). Peat, ca. $0.90 \mathrm{~m}$ thick, at present covered with detritus, was sampled at equidistant levels in section cut by stream crossing the terrace. Samples dated are listed in order from bottom to top of section. Coll. and subm. 1952 by E. Tongiorgi. 


\section{R-11. Lago Pirola 1}

Lower peat, $5 \mathrm{~cm}$ above the bottom.

\section{R-12. Lago Pirola 2}

Peat, $30 \mathrm{~cm}$ above bottom.

\section{R-13. Lago Pirola 3-1}

Peat, $60 \mathrm{~cm}$ above bottom.
$8000 \pm 100$

6050 в.c.

$6400 \pm 200$

4450 в.c.

$5630 \pm 70$ 3680 в.с.

$5210 \pm 150$

3260 в.C.

average: $\quad \mathbf{5 5 5 0} \pm \mathbf{7 0}$

3600 в.с.

$4590 \pm 90$

2640 в.C.

$4850 \pm 150$

2900 в.C.

average: $4660 \pm 80$

2710 B.C.

$3000 \pm 100$

1050 в.c.

\section{R-15. Lago Pirola 4}

Upper peat, $5 \mathrm{~cm}$ below the top.

Comment: the peat, and in particular the wood, were measured to ascertain the time when upper limit of forest was higher than at the present day. Pollen analysis of the peat is being carried out by E. Tongiorgi.

\section{R-39. Massaciuccoli, peat pebble \\ $18,800 \pm 400$ \\ 16,850 в.c.}

Pebble of compressed and hardened peat perforated by pholads, Lago di Massaciuccoli near Torre del Lago, Bassa Versilia, Tuscany $\left(43^{\circ} 50^{\prime} \mathrm{N}\right.$ Lat, $10^{\circ} 09^{\prime} \mathrm{E}$ Long). Subm. 1954 by the late A. C. Blanc. Comment: pebble was brought to surface by suction pumps installed on floating platforms on the lake to extract sand for commercial purposes. Pebble's roundness assumed to have been caused by sea waves on a Pleistocene beach, where it was imbedded with Purpura haemastoma L. var. consul. The beach, at 12 to $26 \mathrm{~m}$ below present sealevel, is inferred from litoral marine sand underlying aeolian sand which has a covering of peat (Blanc A. C., 1937; Blanc, Settepassi, and Tongiorgi, 1953). Pollen analysis of peat pebble indicated a cool-temperate forest, with Pinus predominating over Abies, Picea and Betula such as is found at present in sub-alpine areas (Marchetti and Tongiorgi, 1936). Shells of Purpura imbedded in the sand of the same beach have been dated at Pisa: Pi-116, 5646 \pm 220 (Pisa II). Age of pebble shows that the eroded and transported peat is much older and belongs to the Main Würm phase. Another piece of the pebble was dated by the Lamont Geol. Observatory: L-246, 18,350 \pm 350 (Lamont III). The same age (ca. 18,000 yr) was obtained at Pisa (Tongiorgi, 1963, private communication). 


\section{Lake of Massaciuccoli series}

Humified Phragmites-peat from upper peaty layers of Lago di Massaciuccoli, near Torre del Lago, Bassa Versilia, Tuscany $\left(43^{\circ} 50^{\prime} \mathrm{N}\right.$ Lat, $10^{\circ} 19^{\prime}$ E Long). Peaty layers still being formed, extend over whole marsh of Massaciuccoli, varying in thickness from 1 to $17 \mathrm{~m}$. Samples were taken when peat was removed to extract underlying sand for commercial purposes. At Torre del Lago upper peat is only 2 to $3 \mathrm{~m}$ thick and rests directly on sand (A. C. Blanc, 1937; Blanc, Settepassi and Tongiorgi, 1953). Its entire thickness, from -0.50 to $-3.30 \mathrm{~m}$ below sealevel, is represented by samples coll. at two points not far from each other. Subm. 1954 by the late A. C. Blanc.

\section{Sampling I}

R-40. Peat, $-\mathbf{0 . 5 0} \mathrm{m}$

R-41. Peat, $-1.00 \mathrm{~m}$

R-42. Peat, $-1.50 \mathrm{~m}$

R-43. Peat, $-\mathbf{2 . 0 0} \mathrm{m}$

R-44. Peat-browned siliceous sand, $\mathbf{- 2 . 5 0} \mathrm{m}$

Sampling II

$$
\begin{aligned}
& \text { R-45. Peat, }-0.50 \mathrm{~m} \\
& \text { R-46. } \\
& \text { R-47. }
\end{aligned}
$$

R-51. Peaty siliceous sand, $-\mathbf{3 . 3 0} \mathrm{m}$
$4400 \pm 300$

2450 в.c.

$2950 \pm 250$

1000 в.c.

$4200 \pm 300$

2250 в.c.

$5600 \pm 300$

3650 в.c.

Not dated

$$
1300 \pm 250
$$

A.D. 650

$1750 \pm 250$

A.D. 200

$2400 \pm 300$

450 в.C.

$4800 \pm 300$

2850 в.C.

$2400 \pm 250$

450 в.c.

$2750 \pm 250$

800 в.C.

$2850 \pm 250$

900 в.c.

Comment: two discrepancies between stratigraphical level and age (see samples R-40 and R-48) may be ascribed to defective sampling; doubts about this were expressed by A. C. Blanc when he subm. the samples. It should also be noted that the peats in Sampling I are older at every level than those of Sampling II. Nevertheless, the dates as a whole from the youngest to the oldest give an indication of the overall duration of the upper peat sedimentation. 
Date lists:

\section{REFERENCES}

British Museum I Barker and Mackey, 1959

Cambridge I

Chicago I

Chicago V

Copenhagen III

Copenhagen IV

Groningen II

Groningen IV

Heidelberg I

Lamont III

Pisa I

Pisa II

Stockholm I

Stockholm II

UCLA I

Uppsala I

USGS I

Yale III

Godwin and Willis, 1959

Arnold and Libby, 1951

Libby, 1954

Tauber, 1960

Tauber, 1960

De Vries, Barendsen, and Waterbolk, 1958

Vogel and Waterbolk, 1963

Münnich, 1957

Broecker, Kulp, and Tucek, 1956

Ferrara, Reinhartz, and Tongiorgi, 1959

Ferrara, Fornaca-Rinaldi, and Tongiorgi, 1961

Östlund, 1957

Östlund, 1959

Fergusson and Libby, 1962

Olsson, 1959

Suess, 1954

Barendsen, Deevey, and Gralenski, 1957

Arnold, J. R., and Libby, W. F., 1951, Radiocarbon dates: Science, v. 113, p. 111-120.

Ballario, C., Beneventano, M., De Marco, A., Magistrelli F., Cortesi, C., and Mantovani, T., 1955, Apparatus for carbon-14 dating: Science, v. 121, p. 409-412.

Barendsen, G. W., Deevey, E. S., and Gralenski, L. J., 1957, Yale natural measurements III: Science, v. 126, p. 908-919.

Barker, H., and Mackey, C. J., 1959, British Museum natural radiocarbon measurements I: Am. Jour. Sci. Radioc. Supp., v. 1, p. 81-86.

Bartoli, A., 1961, I pozzi dell'area sacra di Vesta: Monumenti Antichi, Accademia dei Lincei, v. 45 , p. 1-143.

Battaglia, R., 1953, La palafitta del lago di Ledro nel Trentino: Memorie Museo Storia Naturale della Venezia Tridentina, v. 7, p. 3-63.

Bella, F., Blanc, A. C., Blanc, G. A., and Cortesi, C., 1958-61, Una prima datazione con il carbonio-14 della formazione pleistocenica di Grotta Romanelli (Terra d'Otranto) : Quaternaria, v. 5, p. 87-94.

Bella, F., and Cortesi, C., 1957, Attività del Laboratorio dell'Università di Roma per le datazioni con il $\mathrm{C}^{14}$ : Ricerca Scientifica, v. 27, p. 2677-2680.

1960. The $\mathrm{CO}_{2}$-proportional counter of the carbon-14 dating laboratory of the University of Rome: Ricerca Scientifica, v. 30, p. 1969-1977.

Blanc, A. C., 1937, Low levels of the Mediterranean Sea during the pleistocene glaciation: Quart. Jour. Geol. Soc., v. 43, p. 621-651.

Blanc, A. C., Settepassi, F., and Tongiorgi, E., 1953, Excursion au Lac de Massaciuccoli (Plaine côtière de la Basse Versilia) : INQ̉UA VI Congres International, Rome-Pisa, Livret-guide.

Blanc, G. A., 1920, Grotta Romanelli-I Stratigrafia dei depositi e natura e origine di essi : Archiv. Antrop. Etnol., v. 50, fasc. 1-4, p. 65-103. 1928, Grotta Romanelli-II Dati ecologici e paletnologici: Archiv. Antropol. Etnol., v. 58, fasc. 1-4, p. 365-518.

Blanc, G. A., and Cortesi, C., 1941, Interpretazione geochimica delle formazioni quaternarie di Grotta Romanelli (Terra d'Otranto). III Le sostanze umiche fossili: R. Accad. d'Italia Rend., ser. VII, v. 3, p. 33-55.

Blanc, G. A., and Blanc, A. C., 1958-61, Sur une possibilité d'emploi de l'humus fossile dans la méthode de datation par le radiocarbone: Quaternaria, v. 5, p. 75-85.

Breuil, H., 1954, Les datations par le $\mathrm{C}^{14}$ de Lascaux (Dordogne) et Philip Cave (S. W. Africa ): Soc. Prehistoire Française Bull., v. 51, no. 11-12, p. 544-549.

Broecker, W. S., Kulp, J. L., and Tucek, C. S., 1956, Lamont natural radiocarbon measurements III: Science, v. 124, p. 154-165.

Chiappella, V. G., 1955, Grotte di Val Pennavaira: Quaternaria, v. 2, p. 285-286.

1956, Scavo nel giacimento paleolitico superiore di Palidoro (Roma) : Quaternaria, v. 3, p. 263-264. p. 338.

Cipriani, L., 1955, Excavations in Andamanese kitchen-middens: Congrès Int. des Sciences Anthropologiques et Ethnologiques, 4th, Vienna, Actes, Etnologica, v. II, part 1. 
Cipriani, L., 1958-61, Preistoria in atto nella Piccola Andaman: Quaternaria, v. 5, p. 364375. v. 3 , no. 2 , p. $208-209$

Cornaggia-Castiglioni, O., 1955, Nuove ricerche sulla stazione palafitticola della Lagozza di Besnate: Simbrium, v. 2, p. 93-104.

D'Achiardi, G., and Stefanini, G., 1937, Ricerche archeologico-minerarie in Val Fucinaia: Studi Etruschi, v. 11, p. 305-341.

Fergusson, G. J., and Libby, W. F., 1962, UCLA radiocarbon dates I: Radiocarbon, v. 4, p. $109-114$.

Ferrara, G., Reinhartz, M., and Tongiorgi, E., 1959, Carbon-14 dating in Pisa: Am. Jour. Sci. Radioc. Supp., v. 1, p. 103-110.

Ferrara, G., Fornaca-Rinaldi, G., and Tongiorgi, E., 1961, Carbon-14 dating in Pisa II: Radiocarbon, v. 3, p. 99-104.

Focken, C. M., 1960, Radiocarbon Dating Laboratory, Museum of Applied Science of Victoria: Australian Jour. Sci., v. 23, no. 4, p. 127-138.

Godwin, H., and Willis, E. H., 1959, Cambridge natural radiocarbon measurements I: Am. Jour. Sci. Radioc. Supp., v. 1, p. 63-75.

Hammen, T. van der, 1951, Late-glacial flora and periglacial phenomena in the Netherlands: Leidse Geol. Mededel., v. 47, p. 71.

Leale Anfossi, M., 1958-6la, Revisione dei materiali fittili e faunistici provenienti dagli scavi nella Grotta del Pertusello (Val Pennavaira, Albenga): Quaternaria, v. 5, p. 318-320. Quaternaria, v. 5, ponclusione degli scavi al "Pertusello" (Val Pennavaira, Albenga) :
(1920.

Libby, W. F., 1954, Chicago radiocarbon dates V: Science, v. 120, p. 733-742.

Marchetti, M., and Tongiorgi, E., Ricerche sulla vegetazione dell'Etruria marittima. VII Una torba glaciale del Lago di Massaciuccoli (Versilia) : Nuovo Gior. Bot. Ital., n.s., v. 43, p. 872 .

Münnich, K. O., 1957, Heidelberg Natural Radiocarbon Measurements I: Science, v. 126, p. 194-199.

Nydal, R., and Sigmond, R. S., 1957, Radiocarbon dating in Trondheim: Appl. Sci. Research, sec. B, v. 6 , p. 393-400.

Olsson, I., 1959, Uppsala natural radiocarbon measurements I: Am. Jour. Sci. Radioc. Supp., v. 1, p. 87-102.

Östlund, H. G., 1957, Stockholm natural radiocarbon measurements I: Science, v. 126, p. 493-497.

Supp 1959, Stockholm natural radiocarbon measurements II: Am. Jour. Sci. Radioc. Supp., v. 1, p. 35-44.

Radmilli, A. M., 1953, Gli scavi della Grotta Polesini (Ponte Lucano, Tivoli) : Paletnologia Italiana Boll., v. 8, part V, p. 23-31.

Suess, H. E., 1954, U. S. Geological Survey radiocarbon dates I: Science, v. 120, p. 467-473.

Tauber, H., 1960a, Copenhagen natural radiocarbon measurements III : Corrections to radiocarbon dates made with the solid carbon technique: Am. Jour. Sci. Radioc. Supp., v. 2 , p. $5-11$. p. $12-25$ ngiorgi, E., 1937, V-Esame dei carboni provenienti dallo scavo dell'impianto metallurgico: Studi Etruschi, v. 11, p. 331-333.

Vogel, J. C., and Waterbolk, H. T., 1963, Groningen radiocarbon dates IV: Radiocarbon, v. 5 , p. $163-202$.

Vries, HI. de, Barendsen, G. W., and Waterbolk, H. T., 1958, Groningen radiocarbon dates II: Science, v. 127, p. 129-137. 